\title{
Paideusis
}

\section{Plato and Aristotle's Educational Lessons from the Iliad}

\section{Howard James Cannatella}

Volume 15, Number 2, 2006

URI: https://id.erudit.org/iderudit/1072676ar

DOI: https://doi.org/10.7202/1072676ar

See table of contents

Publisher(s)

Canadian Philosophy of Education Society

ISSN

0838-4517 (print)

1916-0348 (digital)

Explore this journal

Cite this article

Cannatella, H. (2006). Plato and Aristotle's Educational Lessons from the Iliad. Paideusis, 15(2), 5-13. https://doi.org/10.7202/1072676ar
Article abstract

Of considerable importance in Plato and Aristotle's educational outlook on the arts was Homer's Iliad. This paper draws out some of the perceived weaknesses and strengths of this epic poem as it relates to the arguments in Plato's Republic and Aristotle's Poetics. I will attempt to do justice to Plato and Aristotle's differing perspectives on the Iliad and their critique of art educational theory and practice. I will show why two philosophers with very different thinking on art education can still significantly affect art teaching practice today.
This document is protected by copyright law. Use of the services of Erudit (including reproduction) is subject to its terms and conditions, which can be viewed online.

https://apropos.erudit.org/en/users/policy-on-use/ 
Paideusis, Volume 15 (2006), No. 2, pp. 5-13

\title{
Plato and Aristotle's Educational Lessons from
} the Iliad

\author{
HOWARD JAMES CANNATELLA
}

Prince George, Canada

Of considerable importance in Plato and Aristotle's educational outlook on the arts was Homer's Iliad. This paper draws out some of the perceived weaknesses and strengths of this epic poem as it relates to the arguments in Plato's Republic and Aristotle's Poetics. I will attempt to do justice to Plato and Aristotle's differing perspectives on the Iliad and their critique of art educational theory and practice. I will show why two philosophers with very different thinking on art education can still significantly affect art teaching practice today.

Without Homer's Iliad, a work synonymous with the ancient Greeks, it is unlikely that Plato and Aristotle could have constructed their theories of art education as they did. To understand Plato and Aristotle's thinking of art education one will invariably have to refer to the Iliad, as without it one will have some difficulty explaining their thoughts, particularly the forces that affected their ideas as they relate to art.

From Plato and many others we know that the Iliad and its performances had a marked affect on public opinion shaping ancient Greek values. Whether we look at it educationally, philosophically, politically, socially, and literary, the Iliad had a profound influence on the populace of ancient Greece to such a degree that Homer was recognized as an important ethical teacher ${ }^{1}$.

One reason why the Iliad would have stimulated admiration among the ancient Greeks is because it is an epic poem, which means that it spoke narratively of "elevated matters" 2 . An epic, by its nature was influenced by the circumstances of great events, actions of life, historical truth, tragedy, heroic figures, ordeals and $a_{w} e^{3}$. This leads us on directly to the fact that the Iliad is a specific type of poem. We also need to be aware that a poet, from the Greek word poiesis meaning to craft or make, was someone competent in the genre of drama, verse, chorus, lyric, and prose.

In a nutshell, the story of the Iliad describes the war waged by the Achaeans and other allies on the city of Troy. The war is provoked when Prince Paris of Troy has taken Menelaus' wife, the beautiful Helen. Menelaus is the brother of King Agamemnon who is the leader of the forces coordinating the

\footnotetext{
${ }^{1}$ Nussbaum, 2001, p. 124.

2 Aristotle, 1995, ch. 6, p. 47.

3 Aristotle, 1995, ch. 10, p. 63.

(C) Copyright 2006. The author, Howard James Cannatella, assigns to Paideusis the right of first publication and educational and non-profit institutions a non-exclusive license to use this document for personal use and in courses of instruction provided that the article is used in full and this copyright statement is reproduced. Any other usage is prohibited without the express permission of the author.
} 
onslaught of Troy. In particular, the story deals with the trials and tribulations of Achilles who is one of the princes of the Achaeans. The story ends when Achilles slays Prince Hector of Troy.

I fear that the synopsis just given is a terribly inadequate one of Homer's poem. This is because while heroes are an indispensable aspect of this poem, the Iliad is also a multilayered and multifaceted story of which the life of Achilles is just one major aspect detachable from the larger picture which was to communicate ancient Greek social cohesion. Homer does not just portray the wrath of Achilles, he also paints, among many other things, the "thought forms" 4 of early Greek culture. Eric Havelock surmises that the poetic with its technical language tended to dominate the thought experiments of early Greek education. The communication of this story would indicate from this perspective, how the community was to embody, live, and enact.

In other ways, Homer draws out a very ingenious, materialist, anti-Other, and globalizing world where nothing is at peace with itself. Similarly, the Iliad is a story that describes how natural it appears to be to take whatever one fancies and whatever is there can be taken should the Gods decree it is right to do so. To take and to fight for it is the 'human' condition of this world. Throughout the Iliad there is always present the incessant desire to demonstrate superiority in battle and place in the world. Meaningful living is constantly viewed in terms of profit. Furthermore, because the Iliad is an epic, we can study the stage craft aspect of this poem. As Aristotle reminds us in his Poetics, Homer understands the technical requirements that can impede and progress those warranted resonances in which certain poetic events, characters, plots, and actions are part of the instructive way poetry emerges; the kind of scene making that helps references, rebuttals and dialogue.

\section{II}

It is time now to confront what Plato and Aristotle thought of Homer's Iliad as their definitive responses to it. The expounding thoughts of both men have implications for the teaching of art. I will first discuss Plato's Republic followed by Aristotle's Poetics.

Plato understood that a pervasive reason why Homer's poems were admired in early Greek culture was due to the demand in his society for collective memorization. Poetry was expected to achieve a degree of collective memorization that preserved Greek oligarchic law and subliminally one's obedience to it. Consequently, poetry would aim to communicate through performance that mysterious unity of existence, the intense reenactment of the one-dimensional flow of human history whose cultural pattern would reinforce at one level the people's complex relation to a brutal belief system. Homer obliges by reciting in the Iliad the names of many figures who played a prominent role in early Greek culture, some of the technical and social rules of governance and the inexorable superstition and insensateness that dictate human affairs. These factors together form a symmetry that underpins the idea that trying to defy the 'natural' law is futile. A strong feeling that life is beyond human control and freedom pervades the Iliad. Plato felt that the populace's desire for poetry was in proportion to its hypnotic affects: those mechanical, repetitive, visual, and social conditioning elements which could conceal life's problems. As Havelock points out, one of the roles of poetry was to reinforce the function of existence as "common to the group and expressive of its coherence as a culture" 5 . Moreover, according to Havelock, the performances of the Iliad would rely on dramatic spectacles, and uncomplicated messages, personification, and honorific communication styles that Plato saw as being used to control the technological thinking and speech acts of the ancient Greeks. In contrast, Aristotle will explain at some length in his Poetics why the principles of poetic construction can be important as a medium of truth and a source of deep moral content.

In the Republic, Plato explains at some length the dangers of indoctrinating the public through the

${ }^{4}$ Havelock, 1963, p. 134.
${ }^{5}$ Havelock, 1963, p. 234. 
strategy of memorization as education. At the heart of this argument is whether memorization as education can really deepen our reasoning skills. Will it, for example, improve our self-critical understanding? Will memory skills alone help us to tell the difference between fact and fiction and right and wrong actions? With this skill at our disposal will we be able to notice problems and find solutions that shed new insights into the human condition? In the Republic Plato is suggesting that recall alone does not discern how we know: reciting perfectly certain lines from Homer's Iliad is different from grasping their meaning. It was the faithfulness and the truthfulness of a poetic cultural tradition that Plato questioned in the Republic: "Don't you understand that we first tell stories to children?" ". A lot follows from this discreet observation. Plato asks what is suitable for children to read, what are the moral truths of life that one should learn about and how can we protect children if "[T] he young can't distinguish what is allegorical from what isn't, and the opinions they absorb at that age are hard to erase and apt to become unalterable" 7 . He surmises that fact and fiction are often too difficult to tell apart in poetry. A poet was at times too inclined to represent falsehoods and be lax about the moral impact of his work on the citizens of Ancient Greek societies. Furthermore, memory recall has relevance for Plato only in relation to its journey; the cumulative and shaping value of its force. That the good Platonically is not in proportion to what we can remember but in the form of knowledge that it represents, what we can learn from it and why it should be approved.

Most notably in Books Two, Three and Ten of the Republic, Plato analyzes the work of a number of poets but with a particular focus on Homer's Odyssey and Iliad as examples of what he construes should be poetry's role in education. Scattered throughout the Republic, however, are noteworthy elaborations that further help define Plato's understanding of what art is. The Republic represents one of Plato's chief works and it is the only work where he prolongs, in depth, a discussion of art. There are at least three sets of arguments that Plato uses to great effect in the Republic to make his case on the liberty of poetry. Firstly, like Xenophanes ${ }^{8}$ before him, he is unhappy with the way Homer appears to use words for lascivious purposes. He argues that poetry can incite a disregard for the ethical truth. Young people and society in general, he says, can be easily led astray into immoral actions by language of this kind. Regardless the excellent quality of its rhetoric and its wide popularity, a poem is meaningless unless it promotes reason and provides ethical guidance. Hearing, feeling, and seeing are important but for Plato how we know the truth of what we hear, feel, and see, that a spectacle in itself may not cause truth, the "knowledge of what is"" are of even more importance. Plato is clearly concerned with illusory virtue and how goodness and happiness can be portrayed misleadingly. For Plato, poetical works could not generate the kind of self-virtue-governance necessary "as the basic mode of living" ${ }^{10}$. Similarly, the picture of poetry as entertainment, revelry, and amusement ${ }^{11}$ could create tensions in life that Plato feels could give way to hedonism and lack of temperance. He realizes that a society without a firm value system is incapable of holding back injustice ${ }^{12}$. To practice art for the sake of the rewards that might come from it, such as fame and popularity, Plato argues, detaches the good from the work, because what we might get in recompense if incapable of preserving its value.

Secondly, Plato's criticism of poets in general and Homer in particular is not dissimilar to his criticism of painters in Book Ten of the Republic. In Book Ten, Plato suggests that if a painter produces a frivolous simulacrum of reality, nothing in the work can tell us about truth. Havelock argues that Plato's condemnation of art as it relates contentiously to mimetic practice is a central tenet of his educational theory; namely that art in general subverts proper thinking. Plato objects to art, however

\footnotetext{
${ }^{6}$ Plato, 1997, Book II, p. 1015.

${ }^{7}$ Plato, 1997, Book II, p. 1017.

8 Jarrett, 1969, p. 6.

9 Plato, 1997, Book VII, p. 1147.

${ }^{10}$ Havelock, 1963, p. 283.

${ }^{11}$ Collingwood, 1958.

12 Plato, 1997, Book VIII.
} 
good the performance, the image, and the reciting, because he believes that art "cripples the intellect" 13 . The alluring pleasures of the poem's aesthetic language, Plato implies, is hardly innocent; rather it is at times maliciously deceitful. What Plato tries to demonstrate is how justice, truth, and good judgement in life depend less on custom, procedure, and memorization, and more on reason and reasoning. For Plato, a flourishing society is dependent upon a strong artistic, ethical, social, intellectual, and political climate. There is evidence then to support Havelock's claim that the lore of the Iliad was pedagogically designed to reinforce the rules, way of life, and traditions of ancient Greek existence in stereotypical and obedient ways ${ }^{14}$. I draw out from Plato that maybe the power of the mass media entertainment industry is an improper way to educate citizens.

Thirdly, to overcome this dilemma, Plato puts forward an alternative view of poetry. Simply put, poetry must be seen to be beneficial to the city state. According to Plato, for the city state to prosper, it must have a platform of civic virtue and a social ethic which is demonstrably concerned with truth. Plato's educational theory is grounded on the premise that reason and truth are the mainstays of a healthy city state and its educational system. In Plato's eyes, if poetry accepts as its cogent belief the notion of pleasure for pleasure's sake or art for art's sake, ${ }^{15}$ then unequivocally there is every possibility that it is nothing more than self-indulgence. Living a good life would then be impossible, contingent on nothing at all but self-interest and appetites. Plato is troubled by many of his fellow citizens' inability to recognize either the poetic superficiality of a performance or its underlying serious message.

Plato, however, remains adamant: "But you should also know that hymns to the gods and eulogies to good people are the only poetry we can admit into our city" ${ }^{16}$. He argues that the role of a poet like Homer must be to serve the city state, its institutions, laws, and customs. Education becomes coextensive with the limits of the city state and the teaching of poetry. According to Plato, poetry must occupy this same space and be governed by its principles. The idea here is to make the poet a good civil servant and instrumental to it. There is a clear, universally valid aspect to this couched in idealism at one end and fictional coherence at the other; both ends can manipulate how students can recreate the world for themselves. Plato's educational view reflects his reluctance to capitalize on how students make their own way into the world and become aware of themselves, expressing their own voice and deciphering the world through their own unique mode of existence. Contemporary educational thinking may have eclipsed Plato's thinking here. However, Plato would likely reply that the young can be too easily fooled about the good life. That whatever satisfaction students may take in the world from technical accomplishments, they would still not know decently how to curtail the violence of want. Our vulnerability to a materialist world may prevent us from forming instructive truths and concerned behaviours that reflect a greater sense of ourselves.

According to Plato, what distorts and deceives our vision of the world is when "The Lovers of sights and sounds like beautiful sounds, colours, shapes, and everything fashioned out of them, but their thought is unable to see and embrace the nature of the Beautiful itself' ${ }^{17}$. In order to understand the possible shapes and colours of the beautiful, Plato suggests that the young seek out the enduring concept of the Beautiful. Plato found the idea of relativism abhorrent However, what Plato is fundamentally calling for in student education was not just to reach for the transcendental truth of things but also for them to think for themselves, to possess some dialectal reasoning skills that involves questioning and answering, and the cross-examination of positions, to reflect upon their life, to determine ideas that are present in society, to conceptualize various premises, and to engage dialogically with other persons. Inherent, therefore, in his criticism of the Iliad is a world incapable of knowing itself because it is a world unable to examine life and remove what is harmful to it.

\footnotetext{
${ }^{13}$ Havelock, 1963, p. 38.

${ }^{14}$ Havelock, 1963, ch. 4.

15 Plato, 1997, Book X and Havelock, 1963, p. 145.

16 Plato, 1997, Book X, p. 1211.

17 Plato, 1997, Book, V, p. 1102.
} 


\section{III}

The heir to an alternative perspective on Homer's Iliad was Aristotle. Similar to Plato, Aristotle was steeped in Homeric tradition but clearly saw another side to Homer that Plato had difficulty recognizing. Although there is much agreement between Plato and Aristotle; what Plato condemns in Homer's Iliad, Aristotle looks at differently. There is no disputing that Aristotle deliberately builds on Plato's thinking. It is important to note that Aristotle can be seen to be taking up Plato's challenge for the arts "to show that it not only gives pleasure but is beneficial both to the constitutions and to human life"18. In what follows, I will attempt to demonstrate how Aristotle shows the human significance of art for life in ways that address this statement by Plato.

One striking difference between Plato and Aristotle is how more positively Aristotle construes the role of mimesis in art contrary to Plato's description of it in Book Ten of the Republic. Educationally, Aristotle saw the mimetic as playing a significant role in assisting human understanding, believing that it was natural for human beings to contemplate and construct images, actions, tunes, and ideas in mimetic ways. He argues that the mimetic causes learning and enjoyment as one of the most common occurrences in life ${ }^{19}$ that roots being in the world to a quintessential source of human knowledge and wisdom.

Briefly, as Stephen Halliwell states it, the mimetic in art can be the "visual means to represent a visual object" 20 . A poet could therefore use metre, rhythm, melody, rhyme, alliteration, working models, movement, depiction, personification, mood, spectacle, character, pleasure, and repetition as a way to "infer what each element means, for instance, that "this person is so-and-so"21. For Aristotle, mimesis poetically relies on the life of human beings and one's institutionalized ${ }^{22}$ culture. At one level, what he is focusing on how Homer and other poets share in the gravitas of mimetic image making in order to aid public recognition, verification, difference, and similarity as part of our ordinary experiences that determine what things mean to us. The mimetic is seen as conformation and enactment ${ }^{23}$. When he refers to mimesis as enactment ${ }^{24}$, the verb "to enact" is to accomplish, inspire, demonstrate, understand, represent, execute, perform, develop or emulate. Therefore, in its Aristotelian form, mimetic practice can stimulate a multiplicity of conditions that affect learning.

Throughout his Poetics he explains why the mimetic through dramatic action and language can be rich in interpreting human experiences and expression, capable of revealing life as it is lived. That the poet could stimulate the most vivid of pleasures Aristotle saw as relating to its mimetic magnitude. What gives the mimetic magnitude connects to the poem's plot and structure of events. Paradigmatically, in order for the poem's mimetic actions to have elevation, a proper sense of unity is needed with a well constructed design, one that has a "beginning, middle, and end" 25 . A performance of Homer's Iliad was like holding up not simply a single mirror but a many-sided mirror to the populace who, on seeing this, would have experienced fictionally an image of themselves. Although analogy, likeness, or resemblance are extremely important notions, they will not suffice as stand-alone conceptions to describe how the mimetic in art can function. And rather than agree with Plato that art is only inspired image-making ${ }^{26}$, Aristotle suggests that art is a "mode of representation" 27 . In this new

\footnotetext{
18 Plato, 1997, Book X, p. 1212.

19 Aristotle, 1995, ch. 4, p. 37.

${ }^{20}$ Halliwell, 1998, p. 112.

${ }^{21}$ Aristotle, 1995, ch. 4, p. 39.

${ }^{22}$ Halliwell, 2002, p. 154-155.

${ }^{23}$ Halliwell, 1998, ch. 4.

${ }^{24}$ Aristotle, 1995, ch. 6, p. 47.

25 Aristotle, 1995, ch. 7, p. 55.

26 Plato, 2001, Book X.

${ }^{27}$ Halliwell, 1998, p. 127.
} 
perspective on art as representation the mimetic artist is concerned with "one of three objects: the kind of things which were or are the case; the kind of thing that people say and think; the kind of thing that ought to be the case" 28 . The poet works from ready-made stories and his own creations ${ }^{29}$. Aristotle construes Homer as the "supreme poet" 30 of mimetic art and he does so on the basis that above all the poets of his time, he set the standards for dramatic mimesis. Contrary to Plato's notion of what the poet should be in the ideal city of the Republic, it was Homer who demonstrated to Aristotle that "poetry does not have the same standard of correctness as politics, or any other art." 31

From the outset of the Poetics, Aristotle wants to establish how poetry can be transformative in people's lives. However, drama merely as technique is not what Aristotle applauds in poetry but rather how technique (techne - technical thinking as reasoned procedure) is used by poets to aid poiesis. Aristotle holds that the technical skills of the poet help bring about the likelihood that the mimetic enactment is believable. As part of a stage performance with pity or fear in it, for example, a poet needs to aware of "the kinds of things that might occur and are possible in terms of probability and necessity" 32. Techne can be related to the moral good in the sense that it facilitates the kind of action that is necessary to demonstrate the right kind of performance. Form and substance overlap in Aristotle's thinking ${ }^{33}$. Pity and fear being represented in a certain kind of manner must achieve, Aristotle argues, a level of characterization and of deed that typically enables the public to identify and understand these actions. The action must cause the perception of something that brings awareness appropriate to its intended meaning. Hence, the poet must have insight into those things that their audience would commonly accept. It is not, however, tradition per se that Aristotle favours but rather how mimetically it is possible for certain actions in drama to portray life in meaningful ways. Poetry was for him a proper teaching tool, a factor in character education and intellectual virtue. The poet, he maintains, must present in a virtuous manner the disposition, speeches and actions of an agent as it seems to lie in life, they must do everything they can to make actions appear possible, plausible, and credible for the audience. Hardly different from Plato, he asserts that the poet must be rational rather than irrational and must avoid confusing wrong with right action in any depicting visual or oral signals. Aristotle implies that only when the technique (craft) is right will the poetry be able to represent properly its intentions. Aristotle emphasizes artistic intention because it indicates how the art work is to be read, that art works in general have different goals that bear upon the correct way they are to be looked at. Furthermore, we can see that for Aristotle, because dramatic artists did employ the genre or type of art which they deliberately took from the epic, comedy and tragedy traditions; these notions were the regulative principles governing artistic creativity and the conceptual way artists like Homer produced and categorized their work. Teleological culture, therefore, plays a part in Aristotelian thinking here.

Aristotle believes that poetry can be used to examine distinctive role-models whose display on stage can help others recognize virtues like friendship and honesty and vices like greed and cruelty. Poetry, for Aristotle (much like Plato), could arouse not only intense emotional responses, but equally, could inspire people to become better persons. On the one hand, Aristotle does not believe that the poet writing the story should uncritically replicate what the audience wanted to $\operatorname{see}^{34}$. On the other hand, he firmly believes that drama could only educate effectively when it encapsulates human experiences that are the common occurrences of living, where certain actions in performance would produce the desired common recognitions, appropriateness, standards and identities. For Aristotle

\footnotetext{
${ }^{28}$ Aristole, 1995 , ch. 25 , pp. $125-126$

${ }^{29}$ Aristotle, 1995, ch. 17, p. 89.

30 Aristotle, 1995, ch. 4, p. 41.

31 Aristotle, 1995, ch. 25, p. 127.

32 Aristotle, 1995, ch. 9, p. 59.

${ }^{33}$ Halliwell, 1998, p. 5.

${ }^{34}$ Aristotle, 1995, ch. 15, p. 73.
} 
poetry is capable of serious tokenism on life. The well constructed plot of character and action that "reveals moral choice" 35 and intention as ethical dispositions and actions of the agent ${ }^{36}$, sustaining virtuous, weak-willed, vain, or manipulative behaviour was important to Aristotle's general ethic. An agent's moral outlook determines certain kinds of actions that affect consequences by implication. Mimetically, poetry was capable of reflecting this. The events in a play were designed to reveal to the audience in an acceptable manner the kind of moral choices in life, like being courageous, could have on the general public. A play could stimulate what might be good about being courageous, the motivation of it, its just ends, the catastrophe, the difficulties, and the consequences that follow from it, and the prudence of this action. According to Aristotle, in tragic and epic drama, where moral choices define some of the events that transform the play's recognition, the nature of these moral choices should take place within the agent's world and the circumstances of their existence ${ }^{37}$. A poet is expected to dignify with refinement an agent whose actions represent moral excellence. Equally, in the same play, the poet's task is to make all characters believable, so that there is no dispute about them. A drama therefore is to have moral standards and sensitivity in relation to such things as friendship, love, compassion, and justice ${ }^{38}$, and that even when there is adversity or antagonism, sense and probability should always define their character. Certainly for Aristotle, moral choices have a significant affect on how things turn out in a drama, the events that unfold, the wheels of fortune and chance happenings, where life does not so much occur randomly and arbitrarily but rather by design.

Unquestionably, Aristotle felt that the Iliad was "rich in suffering" 39 . When Homer portrays Achilles as "through an epitome of harshness" 40 , what Aristotle admires in this description is how Homer is using an expression to establish an aspect of Achilles' character. This is prudentially important in rendering rationally a perception of Achilles that reflects the character of the man as we might believe it to be. In the Iliad we can see Homer using exaggeration to heighten recognition, provoke agreement, create revulsion, and reverse character identification. The important claim that the Iliad is 'rich in suffering' as a desirable notion to depict in certain stories can revitalize the student by deepening their understanding of the world, particularly of the irrational, unexpected, sad, and unnecessary deaths that in the Iliad reaches epidemic proportions. Aristotle explains suffering as a destructive and painful action ${ }^{41}$ but a necessity in a play when there is considerable agent distress involved. Suffering from a moral point of view can be positively evaluated ${ }^{42}$. It completes the action, arousing our compassion, sympathy, wretchedness, and our emotional participation in the feelings of others. The portrait of suffering in a drama has a relationship and a cause that involves considering the overall structure of the play, the qualities of other characters and their part in this event. When drama is constructed to remind the audience of suffering as we see portrayed in the Iliad, its limit is in the fashioning of adversity, fear, pity, wonder, misery, unexpectedness, trepidation, and fortune ${ }^{43}$. A poem with cruelty in it can have elevation because of how it explains and explores what makes cruelty possible. The form cruelty takes in the poem can give rise to understanding the nature of cruelty as we might experience it occurring in human relationships. The poet's mimetic ability to pay attention to cruelty in life enables the audience to recognize it for what it is, to see what is revealing about it, indicating its depravity. "Recognition, as the very name indicates, is a change from ignorance to knowledge" 44 and Aristotle mentions six ways in which recognition occurs: tokens, memory, identity,

\footnotetext{
35 Aristotle, 1995, ch. 6, p. 53.

${ }^{36}$ Halliwell, 1998, p. 152.

37 Aristotle, 1995, ch. 9.

38 Aristotle, 1995, ch. 11.

39 Aristotle, 1995 , ch. 24 , p. 119.

40 Aristotle, 1995, ch. 16, p. 83.

${ }^{41}$ Aristotle, 1995, ch. 12, p. 67.

${ }^{42}$ Kristjánsson, 2005.

43 Aristotle, 1995, ch. 10, p. 63.

${ }^{44}$ Aristotle, 1995, ch.11, p.65.
} 
reasoning, imagery and events.

Aristotle grants art more autonomy and invocation, and less subordination than does Plato. Furthermore, as Halliwell ${ }^{45}$ mentions, Aristotle's Poetics reveals how learning and understanding in art could manifest cognitive and objectivist production that is over and above personal interpretation. Art production in education is located within the intelligible sphere of knowledge because it represents experiences and actions that connect to logical development. What Aristotle categorizes prescriptively for art in an accommodating way is a "set of theory-laden suppositions about the relations between the individual poet, the genre and the dynamics of cultural change" 46 . By explaining some of the controlled, codified, empirical, and rational canons of art practice, Aristotle lays down formidably various principles of how art in education is produced. Nevertheless, let us also remind ourselves that it was Plato who stated that "craft prescribes-but what is best for his subject" 47 , not what is best for one's own advantage; a statement that Aristotle exploits to the full in his Poetics.

To conclude, both Plato and Aristotle's critique of the Iliad engage us in a fuller understanding of the nature of this work. Their individual thoughts on the Iliad cover a spectrum of issues central to educational practice. Plato and Aristotle each make valid arguments and it is not a case of one being right and the other mistaken. Although there are clear differences between Plato and Aristotle's thinking on art education, it is also the case that they share much in common: symmetrically and complementary to each other. Plato acts in good faith towards techne as he attempts to understand its character, the relevance of it, our human vulnerability to it and how art, mathematics, medicine, trades, philosophy, and politics should employ it and guard against it. Likewise, his analysis of the sensory as something other than the truth cannot be lightly dismissed for the reasons that I have given. Aristotle meets Plato half-way, but then diverges to reconstruct a more positive picture of art education. For Aristotle the teachability of art through mimetic technai is central to learning and understanding in this field because, as remarked, it aids fundamentally the composition and communication of the art work. Artistic production can be ethically beneficial for society in the way that it depicts actions and speeches in fictional-representative ways. The different modes, genres, and types of mimesis that Aristotle mentions in the Poetics conceptually enhance the theoretical and practical knowledge of art creation. Aristotle discusses some of the cognitive experiences, procedures and structures that are typically needed as norms in the intelligible production of results in art making. More so than Plato, he understands the rationale for invention, imagination, passion, and ingenious inspiration in art as those responses whose impetus is in conversation with the type of art, the life of people, and the culture of the art world. I concur with Aristotle that mimetic techne facilitates more than we sometimes realize about how art in education is achieved.

\section{References}

Aristotle (1995). Aristotle's Poetics (S. Halliwell, Trans.). Harvard: Harvard University Press.

Collingwood, R. G. (1958). The principles of art. Oxford: Oxford University Press.

Halliwell, S. (1998). Aristotle's Poetics. Chicago: University of Chicago Press.

Halliwell, S. (2002). The aesthetics of mimesis. Princeton: Princeton University Press.

Havelock, E. A. (1963). Preface to Plato. Harvard: Harvard University Press.

Jarrett, L. J. (1969). The educational theories of the sophists. New York: Teachers College Press, Columbia University.

Kristjánsson, K. (2005). Can we teach justified anger? Journal of Philosophy of Education, 39 (4), 671-689.

\footnotetext{
${ }^{45}$ Halliwell, 1998.

${ }^{46}$ Halliwell, 1998, p. 87.

${ }^{47}$ Plato, 1997, Book I, p. 990.
} 
Nussbaum, M. C. (2001). The fragility of goodness. Cambridge: Cambridge University Press.

Plato (1997). Republic. In Plato, Complete works. (J. M. Cooper, Ed.; pp. 971-1223). Indianapolis: Hackett Publishing.

\section{About the Author}

Howard Cannatella Independent Scholar 7720 St. Denis Place Prince George, BC V2N 4K2

Email: hcannatella@shaw.ca 